\title{
Keraton Ngayogyakarta Hadiningrat: Learning Mathematics Based on Ethnomathematics
}

\author{
M. Yulianti ${ }^{\mathrm{a}, 1}$, I. E. Andari ${ }^{\mathrm{b}, 2}$, D. Nurhayati ${ }^{\mathrm{c}, 3}$ \\ ${ }^{a}$ Universitas Negeri Surabaya, East Java, Indonesia

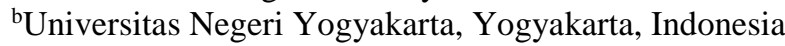 \\ 'MI Qurrota A'yun Sleman, Yogyakarta, Indonesia \\ ${ }^{1}$ maulidayulianti@gmail.com
}

\begin{abstract}
This research aims to explore mathematics and make the steps of learning mathematics that exist in some objects in the Keraton Ngayogyakarta Hadiningrat (Yogyakartan Palace). Some objects had been analyzed based on Realistic Mathematics Education scheme and the learning stage was made with scientific approach. The research results are addressed to all educators as a consideration to make innovations in learning mathematics. The data were collected by observation and literature review that conducted on the buildings and unique objects located in Keraton Yogyakarta. This research shows that there are some unique objects in Yogyakartan Palace that can be used as mathematics learning materials, and the mathematical concepts existed are trapezoid, rhombus, circle, planes, prism, and cylinder.
\end{abstract}

Keywords-component; mathematics based; ethnomathematics

\section{INTRODUCTION}

Ethnomathematics is a means of learning mathematics by culture (D'Ambrosia, U., 1994; D'ambrosio, U., 2001; M. Rosa, et.al. 2016; Blanco-Alvarez, 2016; Septianawati, T., Turmudi, \& Puspita, E., 2017). The term ethnomathematics was firstly introduced by D'Ambrosio a mathematician from Brazil in 1977. Ethnomathematics studies in mathematics can cover all areas. Ethnomathematics using mathematical concepts that widely associated with a variety of mathematical activity, including activity of grouping, counting, measuring, designing, buildings or instrument, playing, specifying a location, and so on (D'Ambrosia,U., 1994; Septianawati, T., Turmudi, \& Puspita, E., 2017)

Nowadays, there are many studies related to ethnomathematics. They are the exploration of ethnomathematics to a cultural object, the implementation of ethnomathematics in learning, and the study of the impact of learning based on ethnomathematics. In Indonesia, the researcher found six studies with the aim of exploring ethnomathematics in Indonesian culture and six research on the implementation of ethnomathematics in learning which resulted good review.

Ethnomathematics is a mathematics that developed in society and corresponds with the local culture. This opens up a pedagogical potential that considers the learners' gained knowledge from learning outside of the classroom. However, in addition to direct learning outside of the classroom, the objects that related to local culture can also be presented by learning media.

Ethnomathematics is in line with Realistic Mathematics Education (RME) (Abdullah, A.S., 2017). Realistic Mathematics Education (RME) is realistic in that case of children learning mathematics through solving problems in the contexts that are meaningful to them (Dickinson, P. and Hough, S., 2012; Zaranis, N. 2017). RME was originated from the Freudenthal Institute in the Netherlands in the 1970s. Realistic Mathematics Education (RME) involves a complete reversal of the teaching/ learning process. The common practice of demonstrating the formal element of a topic, followed by consolidation through exercises with some application problems towards the end of the learning process, does not feature at all. Instead, context problems are used as both a starting point (a route 'into' the mathematics) and the medium through which pupils develop understanding (a route 'through' the mathematics) (Fauzan, A: 2002).

Yogyakarta was one of the special areas in Indonesia because of its royal territory. Thus, it is expected that all forms of cultural heritage in the Sultanate of Yogyakarta can be maintained and maintained its sustainability. By exploring Keraton Yogyakarta as the object of ethnomathematics, it was expected to help maintain and preserve the cultural heritage of Yogyakarta Sultanate and assist in the development of mathematics learning based on eth-mathematics.

In the learning pace, scientific is a concept which obtained appropriately within the process doing by learners (Salkind, N. J., 2008; Trefil, J. and Hazen, R. M., 2000). The implemented scientific approach by using direct or indirect learning mode as a foundation in applying various strategies and learning models is in accordance with the basic competencies to be achieved. So the scientific approach helps learners to find a concept with the experience of the learners themselves. There are five stages of learning in a scientific approach: observing, asking, trying, associating, and communicating.

\section{METHOD}

Some objects were analyzed based on four levels of progressive mathematization in the development of Realistic Mathematics Education model and then made the learning stages with a scientific approach. The research was conducted 
in the central complex of Keraton Ngayogyakarta Hadiningrat Palace or Kera-ton Yogyakarta. Data were collected by observation and literature review. Observation and literature review are done on the unique buildings in Kera-ton Yogyakarta.

In the characteristics of progressive mathematization, there are four levels in the development of the RME model, i.e. situational, referential, general, and formal. The four levels of progressive mathematization can be described in the following formof iceberg.

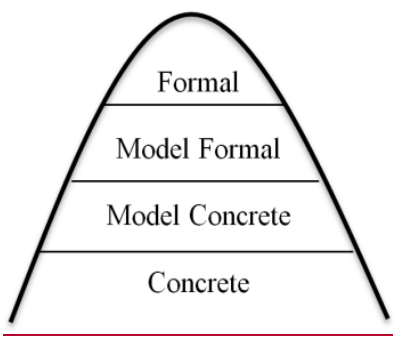

Figure 1: The four Level of progressive mathematization

At a situational level, students still deal with problems or contexts used in learning. The problem or context used is something relevant to the concept that is introduced. Furthermore, at the referential level, students create an image that refers to the context or problem used. At the general level students will be working with models that have been created based on the context, then trying to find a solution from that context or problem. At the last level of the formal level, students will be working with mathematical symbols then formulating the mathematical building concepts.

\section{RESULT AND DISCUSSION}

Physically, Keraton Yogyakarta has seven central complexes namely Siti Hinggil Ler (Northern Balairung), Kamandhungan Ler (North Kamandhungan), Sri Manganti, Kedhaton, Kamagangan, Kamandhungan Kidul (South Kamandhungan), and Siti Hinggil Kidul (South Hall). In addition, Keraton Yogyakarta has a variety of cultural heritage both in the form of ceremonies, ancient and historical objects. On the other hand, Keraton Yogyakarta is also known as a complete customary institution with its tradition. Therefore it was not so surprising that the values of philosophy as well as mythology surrounded the Kraton Yogyakarta still existed.

After going to the palace, researchers only found eight objects due to limited access to take some pictures.

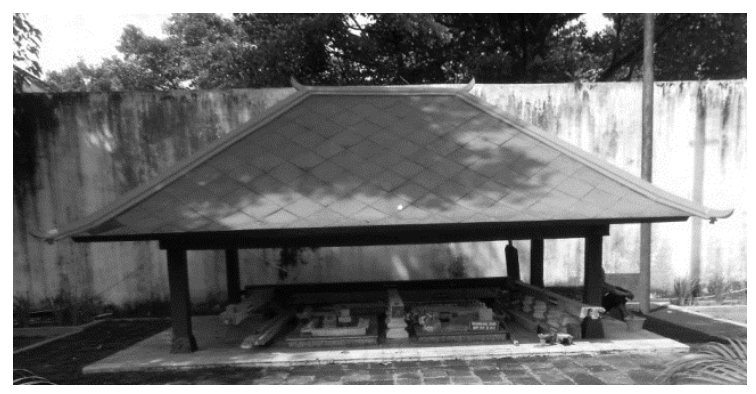

Figure 2. Bangsal Pacaosan Bupati Nayaka
Bangsal Pacaosan Bupati Nayaka functions as a guard palace in Keraton Yogyakarta. On the picture, there is a trapezoidlike on the roof' building.

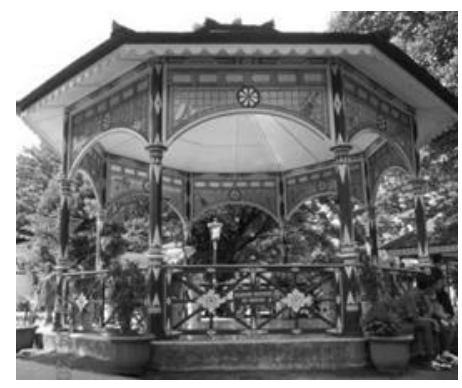

Figure 3. Bangsal Mandalasana

Bangsal Mandalasana is a place of music/platform performances. The building has a regular octagonal floor and the roof is a prism. The mathematical concepts that existed in this building can be used as a material in enrichment, because the levels are quite complicated.

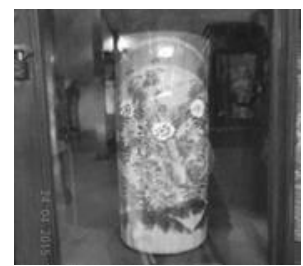

Figure 4. Jar

This cylinder jar is a gift from the Dutch Nobel. Now, this jar is displayed in Keraton Yogyakarta.

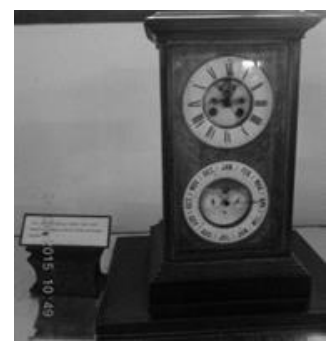

Figure 5. Table Clock

The table clock that is stored in the attic storage room of this palace is a gift from the Netherlands relic of Sri Sultan Hemengkubuwono VIII. In addition, it functions as a reminder of time, this clock is also served as a table decoration. The table clock shows the circle figure, and it can be utilized in learning mathematics.



Figure 6. Bangsal Manis Fence 
Bangsal Manis is used as a banquet place. The building has a quite unique fence. One of the uniqueness is in the form of a fence consisting a wooden arrangement in the shape of a rhombus.

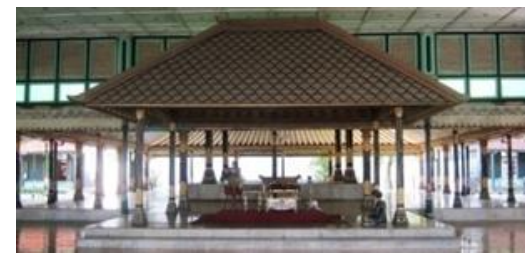

Figure 7. Bangsal Manguntur Takil

This building is the place where the Sultan sits on his throne at official occasions such as the inauguration of the Sultan and Pisowanan Agung. Similar to Bangsal Pacaosan Bupati Nayaka, the roof appearance of this building is in trapezoidal form.

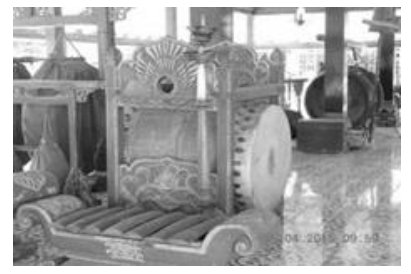

Figure 8. Bedug

It is one of the gamelan devices in the palace. As seen in the picture, it resembles to cylinder form.

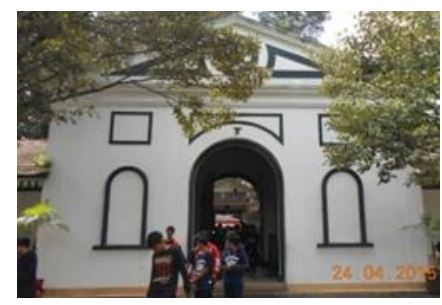

Figure 9. One of the gates in Keraton Yogyakarta

This building is a gateway to the room of the central complex of Keraton Yogyakarta. The gate in this photo looks like a combination of several two-dimensional figures such as rectangles, semicircles and triangles.

The mathematical concepts observed during the study were limited to geometry concept. The mathematical concepts that found were trapezium, rhombus, and circle, combined with planes, prism, and cylinder.

In mathematics learning, the mathematical concept in this object can be learnt by notice this progressive mathematization review.

Realistic Mathematics Education (RME) involves a complete reversal of the teaching/ learning process. By making the progressive mathematics review on each object, every learning step that uses those ethnomathematics learning will later be seen. Next, for helping learners to find a concept, an alternative learning step can be done.
Observing pace include: Learner studied in-group as well as Learner observed the object.

Asking: Learner asked for some questions such as: what figure the object resembled. How many minimum fabrics were required to cover the object? And How many $\mathrm{Kg}$ of minimum rice or sand to fill up the object?

Trying: Learner compared the object with mathematical concept. Learner tried to complete the problem that they had made before.

Associating: Learner illustrated the object and the calculation.

Communicating: Learner presented their discussion result, what kind of figure resembles the object, and how to find the solution to the problem that they had made before.



Figure 10. An example of progressive mathematization review.

Actually, in terms of buildings there are other sides of Keraton Yogyakarta that can be observed. While in terms of culture, there will be many things that can be found and used as an object of ethnic-mathematics.

\section{CONCLUSION}

The results showed that there are some unique objects in Keraton Ngayogyakarta Hadiningrat. They can be used as mathematics learning materials, ie Pacaosan Bupati Nayaka, Bangsal Mandalasana, Jar prizes from the Dutch aristocracy in Keraton Yogyakarta Museum. The table Clock prize from the Netherlands of Sri Sultan Hemengkubuwono VIII in the palace antique storage room. Bangsal Manis Fence, Bangsal Manguntur takil, Bedug, and one of the gates in the Keraton Yogyakarta. Of these several objects, the mathematical concepts are reflected as trapezoid, rhombus, and circle, combine of planes, prism, and cylinder.

\section{REFERENCES}

[1] Abdullah, A.S.2017. Ethnomathematics in Perspective of Sundanese Culture. Journal on Mathematics Education, 8(1), 1-16..

[2] Blanco-Alvarez, H.2016. Ethnomathematcs: A Political Tool For Latin America. RIPE V.6, N.1.

[3] D'Ambrosio, U.1994. Ethnomathematics, the Nature of Mathematics and Mathematics Education. In P. Ernest (ed). Mathematics, Education and Philosophy: an International Perspective: 230-242. London: the former press.

[4] D'Ambrosio. U.2001. What is Ethnomathematics, and How Can It Help Children In Schools. Reston: NCTM.

[5] Dickinson, P. \& Hough, S. 2012. Using Realistic Mathematics Education in UK classrooms. UK. UK National Curriculum. 
[6] Deniz, Omer. 2016. Students' Mathematization Process of the Concept of Slope within the Realistic Mathematics Education. Hacettepe University Journal of Education

[7] Fauzan, A.2002. Applying Realistic Mathematics Education (RME) in Teaching Geometry in Indonesian Primary Schools. Thesis University of Twente Enschede. Press: PrintPartnes Ipskamp-Enschede.

[8] Favilli, Franco.2004. Ethnomathematics and Mathematics Education Proceedings of The 10th International Congress of Mathematics Education Copenhagen. Pisa. Tipografia Editrice Pisana.

[9] Heuvel, Marja.2003. The Didactical Use Of Models In Realistic Mathematics Education: An Example From A Longitudinal Trajectory On Percentage. Netherlands. Kluwer Academic Publishers.

[10] Kwon, Oh Nam. __. Conceptualizing The Realistic Mathematics Education Approach In The Teaching And Learning Of Ordinary Differential Equations. Seoul. Ewha Womans University

[11] Rohrer, AndreaV.2013. The Interdis Ciplinarity of Ethnomathematics: Challenges of Ethnomathematics to Mathematics And Its Education. Revista Latinoamericana de Etnomatemática ,6(3), 78-87

[12] Rosa, M., dkk.2016. Current and Future Perspectives of Ethnomathematics as a Program. ICME-13 Tropical Surveys. Doi: 10.1007/978-3-319-30120-4.
[13] __ Ethnomathematics: the cultural aspects of mathematics. Revista Latinoamericana de Etnomatemática, 4(2). 32-54

[14] Salkind, N. J.2008. Encyclopedia of Educational Psychology. Thousand Oaks: SAGE Publications.

[15] Septianawati, T., Turmudi, \& Puspita, E.2017. Ethnomathematics study: uncovering units of length, area, and volume in Kampung Naga Society. Journal of Physics: Conf. Series 812 (2017) 012021.

[16] Streefland, L. (1991). Fractions in Realistic Mathematics Education: A Developmental Research. Dordrecht: Kluwer Academic

[17] Wilson, Suzanne., dkk.2006. Theories of Learning and Teaching What Do They Mean for Educators?. Washington DC: National Education Association

[18] Zaranis, N.2017. Does the use of Information and Communication Technology through the use of Realistic Mathematics Education help kindergarten students to enhance their effectiveness in addition and subtraction? Preschool \& Primary Education 2017, Volume 5, Issue 1, pp. 46-62.

[19] Zulkardi. 2002. Developing A Learning Environment On Realistic Mathematics Education For Indonesian Student Teachers. Dutch PrintPartners Ipskamp 